\title{
PLURILINGUAL SOCIAL NETWORKS AND THE CREATION OF HYBRID CULTURAL SPACES'
}

\section{REDES SOCIAIS PLURILÍNGUES E A PRODUÇÃO DE ESPAÇOS CULTURAIS HÍBRIDOS}

\author{
Joel Windle* \\ Bárbara Bravo Pires Ferreira**
}

\begin{abstract}
Although plurilingualism is a well-established topic in the international literature, especially in situations of transnational mobility, we still know little about the learning and appropriation of non-standard forms of English by young Brazilians online. Unlike the instrumental uses that predominate in formal English language teaching, digital literacy practices often focus on identity construction and expression, posing questions of race, gender, sexuality, and social status. Based on a digital ethnography of a Facebook page focused on American black popular culture, we analyze the linguistic resources and cultural references drawn upon by participants. The research seeks to understand the perspectives and online practices of young Brazilians, mobilizing theoretical resources from New Literacy Studies to understand the processes of discursive construction and resignification. The results show the importance of virtual spaces for the affirmation of subaltern identities, and at the same time the spatial restriction of some discursive expressions of identity, isolated from other educational and social environments in which the participants circulate. The article concludes by considering the implications for the democratization of foreign language learning in Brazil.
\end{abstract}

Keywords: english; plurilingualism; digital literacy; identity.

\section{RESUMO}

Embora o plurilinguismo seja um tema bem estabelecido na literatura internacional, principalmente em situações de mobilidade transnacional, ainda sabemos pouco sobre a aprendizagem e apropriação de formas não padrão de inglês por jovens brasileiros online. Ao contrário dos usos instrumentais que predominam no ensino formal de língua inglesa, as práticas de letramento digital, muitas vezes, têm como foco a construção e expressão identitária, apresentando questões de raça, gênero, sexualidade e condição social. Com base em uma etnografia digital de uma página do Facebook que trata da cultura popular negra estadunidense, analisamos os recursos linguísticos e referências culturais apropriadas pelos participantes. A pesquisa busca compreender as perspectivas e práticas de jovens brasileiros

* Departament of Modern Languages, Fluminense Federal University (UFF), Niterói, RJ, Brasil. jawindle@gmail.com

** Departament of Modern Languages, Fluminense Federal University (UFF), Niterói, RJ, Brasil. barbarabravo@id.uff.br

1. This research was supported by a PNPD-CAPES fellowship at the Interdisciplinary Graduate Studies Program in Applied Linguistics, Federal University of Rio de Janeiro (08/2018-07/2019) and a PIBIC-UFF scholarship (2017-2018). 
que frequentam a página, mobilizando recursos teóricos dos novos letramentos para entender os processos de construção e ressignificação discursiva. Os resultados mostram a importância do espaço virtual para a afirmação de identidades subalternas, e ao mesmo tempo a restrição de algumas expressões a esse espaço, que fica isolado de outros ambientes educacionais e sociais, nos quais circulam os participantes. $\mathrm{O}$ artigo conclui avaliando as implicações para a democratização da aprendizagem de línguas estrangeiras no Brasil.

Palavras-chave: inglês; plurilingualismo; letramento digital; identidade.

Plurilingualism in the context of globalization has recently generated considerable scholarly interest, with most literature focusing on "developed" countries. The notion refers to the use of a repertoire of linguistic resources from different "languages", refusing a rigid division between them (CANAGARAJAH, 2011). Plurilingual practices may involve non-prestigious linguistic varieties, "cultured" forms and mixed modalities, as in the case of brasiguaios (SANTOS e CAVALCANTI, 2016).

Plurilingualism results in the production of new linguistic forms, which cannot be reduced to the languages mobilized. Much research on the subject focuses on migratory movements, identifying current linguistic practices in important European and North American cities (CANAGARAJAH, 2007; OTSUJI e PENNYCOOK, 2010; BLOMMAERT e RAMPTON, 2011). This phenomenon has also been pointed out in the smaller number of studies available on Brazil and involving the Portuguese language (ALBUQUERQUE, 2010; SEVERO, 2011; SANTOS FERREIRA e SANTOS GOMES, 2015). Many studies point to the increasing global presence of multiple varieties of the English language and to the importance of addressing issues of identity and social power in the analysis of language choices and strategies (RAJAGOPALAN, 2011; RUBDY e ALSAGOFF, 2013; BORDINI e GIMENEZ, 2014).

Research on non-standard varieties of English in Brazil is still very recent, although scholarly interest is increasing (FRANCESCON, SENEFONTE e DE ALMEIDA BARONAS, 2014; ALVES e BATTISTI, 2015). Beyond the context of formal schooling, we know very little about the perspectives and experiences of Brazilians with practices involving English, and almost nothing about the situation of young people who adopt non-standard forms of English language in their daily lives. The work of Moita Lopes and like-minded scholars shows that it is important to understand both the ideological dimensions of English and locally constructed meanings, taking English as a locus of cultural productivity, rather than merely reception (CANAGARAJAH, 2006; PENNYCOOK, 2007; MOITA LOPES, 2008; PENNYCOOK, 2010). The English language currently appears in Brazilian society largely as a vehicle of exclusion, through its association with a white social 
elite, its reputation for being learnt only in private courses or schools, and by virtue of idealization an American native speaker standard (NORTON, 1997; LEFFA, 2002; RAJAGOPALAN, 2005; LIMA, 2011).

Investigation of plurilingual practices amongst young marginalized Brazilian youth in non-school contexts is valuable for understanding the implications of language mixing beyond the dynamics observed by European and North American researchers. As such, the present contribution builds on existing research by showing the importance of virtual spaces, especially with the productive possibilities of Web 2.0, in the construction and defence of subaltern identities in the global south (MOITA LOPES, 2008). Considering the inequalities that permeate Brazilian society and education, we believe such research can help to identify bases for curricular and pedagogical reforms that take into account and affirm the cultural identities of oppressed groups. Some positive support for the proposition is provided by Pennycook (2007), who suggests that English may be appropriated as part of networks of solidarity amongst oppressed groups, and by the hip-hop literacy movement, which shows empowerment connected to black cultural identities and heritage (RICHARDSON, 2003; SILVA, 2012). Of interest here is the appropriation of English as a vector of solidarity among marginalized groups, however, it is not merely English that is remixed through plurilingual practices in Brazil, but the Portuguese language itself, unsettling ideologies of linguistic unity and purity, as well as displacing the authority of "cultured" norms (MOITA-LOPES, 2014).

Some of cultural and technological dimensions of plurilingualism that we seek to investigate have been addressed in some Brazilian research in terms of remix, a concept that reflects shifts in creative production online (BUZATO, 2010; BUZATO et al., 2013; MULICO e DE OLIVEIRA MAIA, 2016). We also draw on the popular Brazilian notion of gambiarra, a term that refers to improvised, temporary and often illicit solutions to problems, and which alludes to the subversion involved in transgressing linguistic and cultural boundaries and hierarchies. The term has been theorized in discussions of teacher's work and textual practices that fall outside of those that are formally recognized and legitimized (WINDLE et al., 2017; WINDLE, 2017).

\section{THE RESEARCH PROJECT AND METHODS}

The research presented here focuses on plurilingual practices involving the English language and American cultural references in a Brazilian Facebook page in which Portuguese was also drawn upon. The project focused on young people who 
had regular contact with the English language through this page, which focused on Afro-American culture and music. The research followed principles of digital ethnography, involving collection and analysis of publications and interviews (KEVIN e KELLY, 2003; LAM, 2006; 2009). The interviews $(n=8)$ dealt with issues of motivation for participation in online communities, perceptions of peers, contact with English its use, and attitudes towards English and English speakers. Interviewees were selected through the pre-existing social networks and an initial interview with the page administrator.

The page analyzed, with a total of 55,000 followers, consisted of posts made predominantly in English (80\%). Analysis of online publications was conducted over 6 months and sought to identify discursive markers contributing to the construction of identities and relations of power. We focused on linguistic strategies of social positioning, often involving questions of racialization and authenticity (WINDLE, 2008; MELO e MOITA LOPES, 2014; SAUNTSON, 2016), as well as examining the global circulation of cultural and linguistic practices (PENNYCOOK, 2007).

Our analysis of linguistic moves between languages seeks to build on the concept of "translanguaging", often used to typify plurilingual practices. The situations we examine go beyond those of a homogeneous system used by an individual as a second language speaker, or a fluent alternation of multilingual speakers of two languages, as is the case in bilingual code-switching. Thus, we seek to identify how, within interactions and discourses, a range of linguistic resources and repertoires are constructed (OTSUJI e PENNYCOOK, 2010; BLOMMAERT e RAMPTON, 2011; RUBDY and ALSAGOFF, 2013). Adding the notion of gambiarra as a particular kind of subversive and underground translanguaging, we further disrupt the idea of language as a closed entity, showing how users of a given language always modify meanings. Indeed interviewees, and other users of the page analyzed here, take a transgressive attitude towards accepted language patterns in all languages and cultural repertoires mobilized. By establishing a playful interaction between languages and cultures, through postings on social networks, the linguistic exchanges we examine are characterized by improvisation and remixing of cultural elements that reference multiple linguistic and cultural scales (BLOMMAERT e RAMPTON, 2011), while reasserting agency for those marginalized within these scales.

The use of the English language, centered on colloquiality, offers socially, racially and culturally marginalized speakers of Portuguese a chance to create a new speaking position that is not that does not rely on the authority of the native English speaker or the authorized speaker of socially acceptable Portuguese. The 
black and working-class youth participating in the study can indeed be considered to be outside the of the circle of subjects who use standard and formal varieties of the Portuguese language. Most suffer from the linguistic prejudice that silences and stigmatize Brazilians from poor and rural areas, as well as those from, favelas and urban peripheries. Common Brazilian Portuguese terms for "gibberish" reference black and indigenous speakers (BAGNO, 2017). The meaning-making undertaken in the exchanges we analyze is therefore framed by this position of linguistic marginality in the first language community, and identification with English outside of the normative reference-point of that language community, particularly as constructed in formal learning settings. The practices we present below are intimately tied to the identities projected by popular culture, particularly music, which is the main topic of the online community analyzed.

\section{ENGLISH FROM THE GHETTO TO THE FAVELA}

The page name, in non-standard English, lexically signals identification with black and hip-hop cultures, and references African American Vernacular English (AAVE) phonology through its informal spelling. Created in 2013 by a Brazilian teenager from the urban periphery of Rio de Janeiro, and aimed at a Brazilian audience - at least in its beginning - The page posts focus on pop divas and American celebrities, making constant use of English in texts, images, memes, gifs and videos. Responses to the posts are mostly made by Brazilians and in English.

This predominance of English is surprising, in light of its almost exclusive association with social elites in Brazil. While it is difficult to measure the overall social composition of those who interact on the researched page, the interviewees, six young men and two young women, can all be considered members of oppressed groups in Brazil, whether by race, gender, sexuality or social class, as well as their location in urban peripheries. Of these participants, four considered that they did not have an advanced level of English, even though all had undertaken English classes at school. Most of their English language skills, they reported, came from films, television and music. Only two of the participants claimed an advanced level of English, based on completion of private courses.

The participants shared a number of common views about the page and its linguistic positioning. The socio-cultural understanding of language developed by the participants, is most clearly articulated by the page administrator, Davi [male, 21], when he distinguished between two types of English, the "traditional" and the "informal": 
D: But the English I use is also not the traditional American, it's English, it's English that's used in the ghetto, the English I learned watching movies, movies that go on in the American ghetto. I do not write correctly, either, in the traditional way. I write from, in an informal way, that it's the same way they ... that they write. [...] Many people correct some posts I write there, correct below, but most of the time I write on purpose. ${ }^{2}$

Another interviewee André [male, 22], commented, when asked about understanding what is written in English on the page, "So it's ... my English is not perfect like that. But you can understand 100 percent". Even assuming the frequent use of African American Vernacular slang may impede some understanding, he noted "I find their English quite easy, yes, despite having a lot of slang. ". Further commenting on this issue, another interviewee, Lucas [male, 23] affirmed:

Look, I, I feel that it is very, very black, so... it has to do a lot with black culture indeed [...] At least the, the black English that I have contact with, I, I find it pretty similar, the slang also, is very similar. ${ }^{3}$

Thus, the use of AAVE on the page demanded a previous "insider" knowledge of its readers, to be recognizable and understandable as a marker of racialized social identity, moving beyond the recognizable features of standard English, represented in Brazil by commercial courses.

The statements made by the participants indicated recognition and appreciation of this standard English, in this case interpreted as "perfect" and "traditional", but also, and more deeply, they indicated a belief in the existence of an opposition between two sides of a language that, in this context, although in tension, were not totally polarized. What they assumed to be "correct" or "perfect" English was formal English, which is learned in schools and courses and is therefore valued by the upper echelons of Brazilian society as a marker of distinction and a tool for domination in educational and employment. However, when members of this online community made the linguistic, and consequently social choice, of using English on the page, through colloquiality and slang, in a space of informality constructed through AAVE phonics and lexicon, they detached themselves from the idea of subordination and imperialism, and from English considered by them

2. Our translation from the Portuguese, the language of the interview. The original follows: D: Mas o inglês que eu uso também não é o tradicional americano, é o inglês, é inglês que é usado no gueto, o inglês que aprendi vendo filme, filme que se passa no gueto americano. Eu não escrevo da forma correta, também, da forma tradicional. Eu escrevo da, de uma forma informal, que é do mesmo jeito que eles...que eles escrevem. [...] Muita gente corrige alguns posts que eu escrevo lá, corrigem embaixo, mas a maioria das vezes eu escrevo de propósito.

3. "Olha, eu...eu sinto que ele é bastante, bastante negro, é...tem muito a ver com a cultura negra mesmo. [...] Pelo menos o, o inglês negro que eu tenho contato eu, eu achei bastante parecido, as gírias também são bem parecidas." 
to be "correct". Instead they adapted English in their exchanges, so as to bring it closer to their own social identities, and to their own colloquial uses of their first language, Portuguese.

It is important to note that all participants, even those with a high level of English proficiency, said they needed help at some point in order to understand the slang and English expressions used on the page. And help was provided in two main ways: through the page's own comments section, and through the "Urban Dictionary" website. The first option functioned as an explanatory extension of the posting, used by all the interviewees, in which the participants responded to what was published, either through an extension of the English publication, by some type of translation into Portuguese, or even by asking for help in order to interact with other readers who may not understand the meaning of the post and / or be helped at the same time. The second source of assistance was a popular user-constructed page, functioning as an external database for the slang used in the online community researched, although not specifically designed for second or foreign language users. Rather, Urban Dictionary sets itself up as a gatekeeper and guide to cultural subgroups - including those defined by age, location, interests or status - implicitly constructing linguistic meaning with reference to subaltern or subcultural norms and practices.

\section{PROJECTING HYBRID SOCIAL IDENTITIES THROUGH APPROPRIATION, REMIX AND GAMBIARRA}

To make sense of this unusual linguistic situation, we draw on the concepts of remix and gambiarra, in which the speakers of a language, at the same time as they are exposed to previous models of meaning, modify meanings through new uses and combinations of discourses (MULICO e DE OLIVEIRA MAIA, 2016; WINDLE et al., 2017; WINDLE, 2017). Remix appears to be an apt way to describe how users of the page took an existing model of English with which they had contact through films, music and videos, and as group in a social network, modified the original meanings and references. The idea of gambiarra helps to move beyond the idea of an organized creative process and take into account the informality, spontaneity and communal nature of interactions on the page, in which iteration with variation is in keeping with the notion of remix, while the "improvised" nature of such remixes is in keeping with the idea of gambiarra.

In posting on current events in US popular culture, the page administrator drew links to daily problems and pleasures of life in Brazilian urban peripheries, 
including precarious public transport, flirting with crushes and confronting racism, projecting the persona of a "sassy" black girl from an American ghetto. Responses mostly adopted similar personas, riffing on the original news items to humorously link them to their own circumstances, actions and fantasies. The personas adopted on the page were, for the most part, taken up by marginalized youth, rather than those who are in positions of power. The page administrator, for example, was a young black man from the northern zone of Rio de Janeiro who had never left his home state. His persona was reworking of his own speaking position as a queer man of color speaking back to a racist, misogynistic and homophobic society.

Despite the page administrator, asserting "I have never posted anything my own, anything personal", the very choice of creating content based on American pop culture in English engaged a level of identity work and reworking. By assuming a social and linguistic "alter ego" - as the page administrator called it - a new identity was developed and consequently a new discursive remix was created. $\mathrm{He}$ observed "... I had to think, that I had to speak, and that I had to have reactions like a black American". In this way, the virtual platform offered the opportunity for linguistic and social change at both private and public level in the appropriation of a language that is both prohibited on an ideological level as the preserve of the well-educated urban elite, and permeable through the repertoire of AAVE and its associated, marginalized, social identities.

This form of hybrid and transgressive communication, as suggested by Mulico and Maia (2016), changes both the subject and space around them, because this phenomenon reached all of the participants of the page, who began re-creating, remixing meanings within the context of the group. As a standard-setting agent, the administrator, by presenting a certain type of persona, made his / her behavior acceptable and desirable, and the participants became active actors in this linguistic (re) construction process within a virtual space, which ultimately generated new linguistic possibilities, both in Portuguese and in English.

Despite this apparently liberating appropriation and self-projection into scenarios of African-American empowerment, participants expressed ambiguity about the legitimacy value of the language used and their own social status. In a socio-political scope of the English use on the page, we can find a of duality, through the impressions of two of the interviewees. One of them, José [male, 21] believed that even with the regular use of English, the page is "half favela", which points to the social stigma attached to informal English and AAVE usage, even for its users. The posts, although based on American pop culture, and singers considered pop divas, 
established a cultural space linked to what is peripheral both in the US, through ghetto "talk", and Brazilian marginalized spaces and identities, without necessarily questioning established hierarchies (i.e., evocations of these territories sometimes involved self-deprecation). This type of transnational remix of the global marginal involved a high level of self-referential and territorially-defined insider commentary. On one hand, this opened up the appropriation of AAVE as an avenue to express local concerns, but on the other, it marked the page off from the "origins" and potential threats of potentially negative judgements by "native" and "authentic" speakers. Lucia [female, 24], noted:

I think that, that it is really easier [to communicate], than probably an American webpage, even with the slang, if it were an American page, I think I would not even go on it or be able to dialogue and everything else. ${ }^{4}$

Lucy's comments suggest that the page is appealing precisely because it is Brazilians who are talking to each other using this discourse, and in ways that would perhaps not be possible on a page for an American audience, even as this cuts off some of the possibility of a transnational dialogue. It is ironic that the mobilization of linguistic resources for referencing similar marginalized positions is seen as too intimidating to be undertaken beyond local linguistic and social communities.

Some other participants also pointed to the distance that exists between the social world referenced by US pop-culture and linguistic turns and life in Brazil. Paulo [male, 20] drew attention to the "different reality" of the US, which ends up "not coming close to" Brazilian reality, which also points to the possibility of nonidentification, which, in this case, shows that the page is not merely a celebration of overlapping discourses and realities. These points are important for curtailing the tendency in the research literature to equate the global spread of English and cultural movements such as hip-hop with global communications between groups involved in these cultural and linguistic movements. It is possible for groups mobilizing similar cultural and linguistic resources - to the extent that they are almost indistinguishable to the outside observer - and yet remain isolated both from each other and from wider social structures of communication, access and legitimacy.

4. "Então acho que, que realmente fica bem mais fácil, provavelmente uma página americana até mesmo com as gírias, seria bem mais difícil de, acho que eu nem entraria assim, na questão de tipo, pra poder dialogar e tudo mais." 


\section{THE SOCIOLINGUISTIC STRUCTURES OF ONLINE INTERACTIONS}

From our collection of posts from this particular page over four months of the project, between September and January 2017, we focus here on two that highlight the group's sociolinguistic practices as forms of community building.

The first post (Figure 1), made after the announcement that singer Beyoncé had been cast to play the character Nala in the Lion King, was very popular among the users of the page, attracting over 3,000 "likes" and 300 comments. The original purpose was to create humor through a text based on the singer's performances, mixing references to the songs "Independent Women" and "Yeoncé", while alluding to the film, exchanging the word 'Women' for 'Lions', and the expression 'Hey' for 'Rawr'. In short, a remix of the lyrics to include intertextual references. In addition, there is a visual cue in the image, the inclusion of a shadow of the singer, as if she were already part of the film, summoning the other characters as part of a performance.

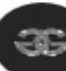

High as Sh.t

28 de novembro de 2017 -

Beyoncé in The Lion King, (2019)

Where my independent Lions at? Let me hear y'all say RAWWWWR MS CARTER

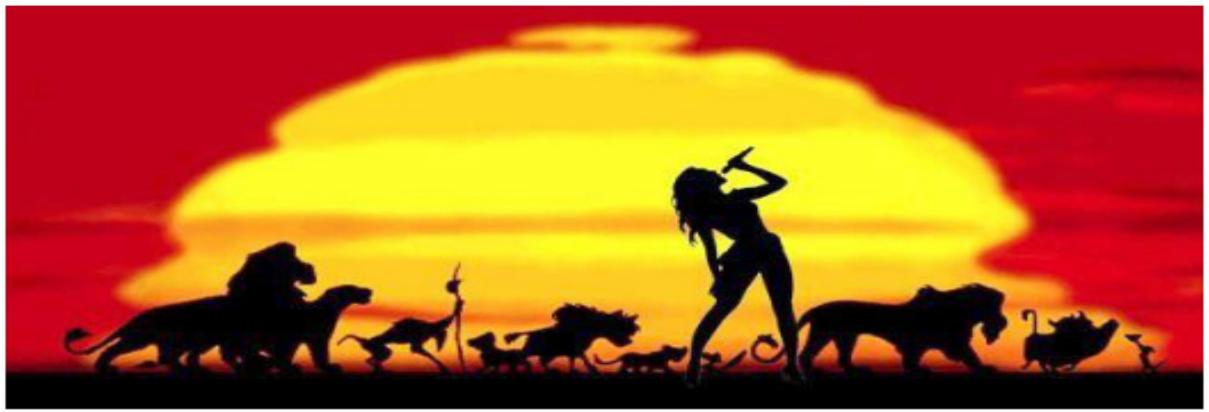

Figure 1

In this case, it is interesting to note that the post serves as a discursive structure, or design, for the comments, because it provides a model for remixing Beyoncé lyrics with reference to the Lion King, as in the examples shown below (Figure 2). 
Okay ladies now let's get in LIONation, cause i slayy

Curtir - Responder - 22 sem

Simba, can you handle this?

Curtir-Responder - 22 sem

$\rightarrow 3$ Respostas

\section{own are in a box to the left}

To the left to the left, all the lands you

\section{Curtir-Resoonder $\cdot 22$ sem}

Figure 2

Here, participants were pushed to rework the meanings of familiar phrases Beyoncé's songs, but keeping the same humorous tone as the original post. The humorous lexical indexing of the Lion King is achieved through the words 'Simba' and 'lands' and also with the shifting of the expression "formation" into "LIONation". This points to a particular linguistic attitude towards the use of English, which follows a pattern visible in other comments. There is, in this post, the opportunity to be understood (recognised as a legitimate participant in the joke) only by swapping one of the English expressions, maintaining the balance between the two references - the film and the lyrics. These contributions do not reflect concern with formal linguistic standards, but with the construction of connotational meaning within a specific social space.

The second post (Figure 3) is focused on American celebrity Kim Kardashian, published when she announced on Twitter "Chicago West" as the name chosen for her daughter. The post reposts Kardashian's twitter announcement with a wry comment. And, despite attracting less attention than first post analyzed - with around 700 "likes" and 90 comments, it presents a different pattern in responses that makes more direct connections to Brazil. 


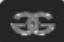

High as Sh.t

19 de janeiro - 8

Kanye and Kim named their new baby CHICAGO WEST.

I dont know why but im not suprised

\section{Chicago West.}

\section{CHICAGO \\ WEST}

Figure 3

Responses to this post, examples of translanguaging (CANAGARAJAH, 2011), showed greater variation in the modifications and interpretations of original news. Most comments, humorously substituted Chicago for Brazilian locations to create celebrity baby names (Figure 4). These locations generate both identification and humor, replacing the exotic and glamourous Chicago with poor neighborhoods in the northern region of Rio de Janeiro. 


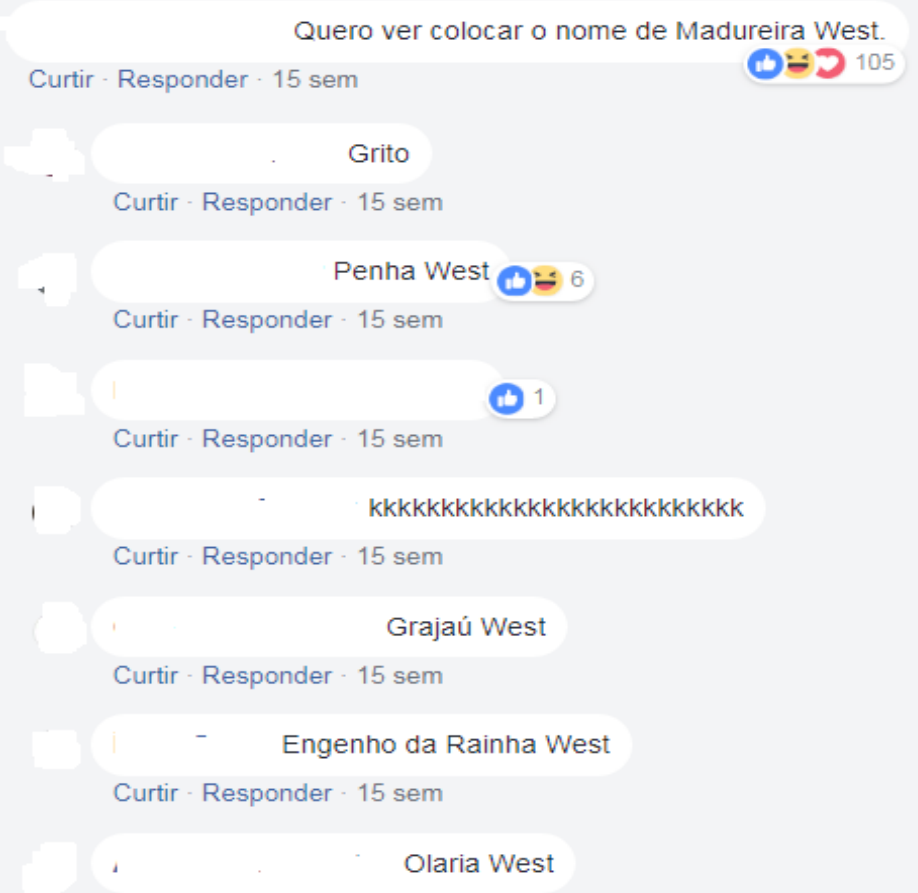

Figure 4

Other translanguaging comments included questions about the sex of the child (Figure 5), maintaining a symmetrical use of informal contractions in a move from Portuguese $($ nera $=$ não era $)$ to English $($ gurl $=$ girl $)$. These questions arose since the baby was a girl, but the name Chicago appears, to Portuguese speakers, to have a masculine inflection due to the ending " $\mathrm{o}$ " rather than the feminine "a". This questioning led one of the participants to comment "apparently it's a 'meninë', in an attempt to get around - while also destabilizing - the gender issue in the composition of proper nouns. The neologism "menine" (kid), which does not display a legible gender inflection, is an example of an in-group subversion or queering of Portuguese, which requires all nouns to have a gender. 


\section{BUT NERA GURL PEOPLE????? \\ Curtir - Responder - 20 sem \\ (1) 24}

Venice and my son Hollywood

I just decide that my daughter will be named

Curtir - Responder - 20 sem

Chic A Go

Chi Ca Go

Chica Go... Ver mais

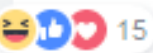

Curtir - Responder - 20 sem

dissapointed

i'm not impressed but i'm

Curtir - Responder - 20 sem

\section{Pais não uns demônios \\ (1) 2 눈 14 \\ Curtir - Responder - 20 sem}

So it was a girl or a boy $10=12$
Curtir - Responder - 20 sem

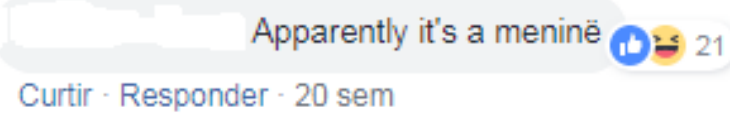

Figure 5

We can also see how the subversion of English and Portuguese through the queering of gendered nouns is a kind of resourcefulness associated with gambiarra - improvisation with available materials. The use of both languages on the page is deliberately disorderly, and often happens in the same sentence, as in the case of "BUT NERA GURL PEOPLE?" However, this phrase is also an example of intertextuality, referring to the viral Brazilian video: "Higor nera gay", in which there is the questioning of the sexuality of 'Higor'. The sentence, although a written comment, bears strong traces of orality through the use and phonetic spelling of contractions in English and Portuguese, and the lack of punctuation. 
Through these exchanges, we can see a valorization of word-play and translanguaging that display a high level of metalinguistic awareness. We can also identify the projection of self into international hip-hop news through the invention of baby names that reference poor neighborhoods in Rio de Janeiro, and through responses that index local jokes and memes. The attribution of a non-binary gender through a gambiarra (an inventive bypassing of the grammatical structures for marking gender in Portuguese) also references a wider movement to challenge normative gender and sexual norms. Therefore, what may appear as linguistic moves are in fact important signals of social identification and, indeed, resistance within a homophobic and misogynistic society.

\section{CONCLUSION}

The administrator and users of the page analyzed above display impressive inventiveness towards the interaction between languages and cultures, incorporating elements of one language into the other and, with that, shifting their own identities as speakers of Portuguese and English. However, this case examined also presents a number of ambiguities that trouble work on plurilingualism and translanguaging as globalizing linguistic and communicative phenomena. While the very mixing of linguistic norms and repertoires is indicative of subversion, in the eyes of participants themselves, boundaries remain in prestige, legitimacy and ownership between nonnative and "native" speakers of English. This makes it possible for participants to feel included in a plurilingual virtual space but only with the comfort of sharing their hybrid linguistic practices almost exclusively amongst fellow Brazilians. We can see how these language users dissociate themselves from what is seen as "correct" and "traditional", which still prevails in schools and courses, retaining a self-perception that is at times proud, but at others internalizes a negative view of the informal, peripheral and oral forms with which they feel most comfortable.

The persistence of some restrictive linguistic ideologies in this group suggests that it is important to recognize that peripheral spaces and identities can remain separated communicatively even as they draw on similar linguistic and cultural repertoires, and engage in interactions that generate and replicate expressions of solidarity. The Brazilian participants in this page are drawn together by common interests and tastes that, for the most part, remain marginalized in relation to Brazilian social institutions, particularly formal schooling. Online exchanges with like-minded individuals can mask differences in opportunities and living conditions amongst participants, but can also provide, for a time at least, a safe space for the 
celebration of racial, sexual and gender identities that are often violently repressed off-line and in wider society.

The implications of these limitations and ambiguities are that plurilingual practices are, of themselves, insufficient to effect meaningful social change, even if they conjure up transgressive social imaginaries and involve rich forms of linguistic and cultural learning. The kinds of territorial segregation, racial oppression and class exploitation that underpin the linguistic and social norms against which some of the plurilingual practices analyzed here are positioned largely remain intact. A key outstanding question, therefore, is how those engaged in online communities from marginalized social positions can build on their linguistic exchanges in ways that construct political projects and collective strategies both locally, and, breaking through the barriers of linguistic shame, internationally.

\section{REFERENCES}

ALBUQUERQUE, J. L. C. (2010). Conflito e integração nas fronteiras dos brasiguaios. Caderno CRH, v. 23, n. 60, p. 579-590.

ALVES, U. K.; BATTISTI, E. (2015). Variação e Diversidade Linguística no EnsinoAprendizagem de Língua Inglesa na Graduação em Letras. Cadernos de Letras da UFF, v. 24, n. 48, p. 291-311.

BAGNO, M. (2017). Dicionário Crítico de Sociolinguística. São Paulo: Parábola.

BLOMMAERT, J.; RAMPTON, B. (2011). Language and superdiversity. Diversities, v. 13, n. 2, p. 1-21.

BORDINI, M.; GIMENEZ, T. (2014). Estudos sobre inglês como língua franca no Brasil (2005-2012): uma metassíntese qualitativa. Signum: Estudos da Linguagem, v. 17, n. 1, p. $10-43$.

BUZATO, M. E. K. (2010). Cultura digital, Educação e Letramento: conflitos, desafios, perspectivas. Jornada de Letras, São Carlos, Editora da UFSCar, p. 69-88.

BUZATO, M. E. K., SILVA, D. P. D., COSER, D. S., BARROS, N. N. D., \& SACHS, R. S. (2013). Remix, mashup, paródia e companhia: por uma taxonomia multidimensional da transtextualidade na cultura digital. Revista Brasileira de Linguística Aplicada, v. 13, n. 4, p. 1191-1221. 
CANAGARAJAH, S. (2006). Negotiating the local in English as a lingua franca. Anmual Review of Applied Linguistics, v. 26, p. 197-218.

CANAGARAJAH, S. (2007). Lingua franca English, multilingual communities, and language acquisition. The Modern Language Journal, v. 91, n. s1, p. 923-939.

CANAGARAJAH, S. (2011). Translanguaging in the classroom: Emerging issues for research and pedagogy. Applied linguistics review, v. 2, p. 1-28.

FRANCESCON, P. K.; SENEFONTE, F. H. R.; DE ALMEIDA BARONAS, J. E. (2014). Variação Linguística no Ensino de Língua Inglesa. Entrelinbas, v. 7, n. 2, p. 209-221.

KEVIN, M. L.; KELLY, K. M. (2003). Tracing the everyday'sitings' of adolescents on the internet: A strategic adaptation of ethnography across online and offline spaces. Education, Communication \& Information, v. 3, n. 2, p. 211-240.

LAM, W. S. E. (2006). Culture and learning in the context of globalization: Research directions. Review of research in education, p. 213-237.

LAM, W. S. E. (2009). Multiliteracies on instant messaging in negotiating local, translocal, and transnational affiliations: A case of an adolescent immigrant. Reading Research Quarterly, v. 44, n. 4, p. 377-397.

LEFFA, V. J. (2002). Teaching English as a multinational language. The Linguistic Association of Korea Journal, v. 10, n. 1, p. 29-53.

LIMA, D. C. (2011). Inglês em escolas públicas não funciona? uma questão, múltiplos olbares. São Paulo: Parábola.

MELO, G. C. V.; MOITA LOPES, L. P. (2014). Ordens de indexicalidade mobilizadas nas performances discursivas de um garoto de programa: ser negro e homoerótico. Linguagem em (Dis) curso, v. 14, n. 3, p. 653-673.

MOITA-LOPES, L. P. (2014). Global Portuguese: linguistic ideologies in late modernity. New York: Routledge.

MOITA LOPES, L. P. (2008). Inglês e globalização em uma epistemologia de fronteira: ideologia lingüística para tempos híbridos. DELTA: Documentação e Estudos em Linguística Teórica e Aplicada, v. 24, n. 2, p. 309-340. 
MULICO, L. V.; DE OLIVEIRA MAIA, J. (2016). Descoleções e remixes na aprendizagem de língua inglesa: um estudo de caso em uma escola pública. Trabalbos em Linguística Aplicada, v. 55, n. 2, p. 319-351.

NORTON, B. (1997). Language, identity, and the ownership of English. TESOL quarterly, p. 409-429.

OTSUJI, E.; PENNYCOOK, A. (2010). Metrolingualism: Fixity, fluidity and language in flux. International Journal of Multilingualism, v. 7, n. 3, p. 240-254.

PENNYCOOK, A. (2007). Language, localization, and the real: Hip-hop and the global spread of authenticity. Journal of Language, Identity, and Education, v. 6, n. 2, p. 101-115.

PENNYCOOK, A. (2010). Language as a local practice. New York: Routledge.

RAJAGOPALAN, K. (2005). A geopolítica da língua inglesa e seus reflexos no Brasil. São Paulo: Parábola Editorial, 135-159.

RAJAGOPALAN, K. O (2011). "World English"-um fenômeno muito mal compreendido. In: GIMENEZ, G.;CALVO, L. C. S., et al (Ed.). Inglês Como Lingua Franca: EnsinoAprendizagem e Formaçao de Professores. Campinas: Pontes, p.45-57.

RUBDY, R.; ALSAGOFF, L. (2013). The global-local interface and bybridity: Exploring language and identity. Bristol: Multilingual Matters.

SANTOS FERREIRA, G. V.; SANTOS GOMES, N. (2015). World English em Manhattan Connection: Uma Análise dos Anglicismos na Linguagem Televisiva. Revista Pbilologus, v. 21, n. 63

SANTOS, M. E. P.; CAVALCANTI, M. C. (2016). Identidades híbridas, língua (gens) provisórias-alunos "brasiguaios" em foco. Trabalhos em Linguística Aplicada, v. 47, n. 2, p. 429-446.

SAUNTSON, H. (2016). Authenticating Sexual Diversity in School: Examining Sociolinguistic Constructions of Young People's Sexual Identities. Journal of Language, Identity \& Education, v. 15, n. 1, p. 17-31, 2016.

SEVERO, C. G. (2011). Questões de língua, identidade e poder: hibridismos em Timor Leste. Revista Brasileira de Linguística Aplicada, v. 11, n. 1, p. 95-113.

WEENINK, D. (2008). Cosmopolitanism as a Form of Capital. Sociology, v. 42, n. 6, p. 1089-1106. 
WINDLE, J. MATIAS SILVA, F.; MORAES, J.; CABRAL, S. (2017). A produção de conhecimento teórico no sul global: Repensando a pedagogia de multiletramentos. In: TAKAKI, N. e MONTE MÓR, W. M. (Ed.). Construções de Sentido e Letramento Digital Crítico na Área de Linguas/Linguagens. São Paulo: Pontes, p. 101-118.

WINDLE, J. A. (2008). The racialisation of African youth in Australia. Social Identities, v. 14 , n. 5, p. 14.

WINDLE, J. A. (2017). Hidden features in global knowledge production:(re) positioning theory and practice in academic writing. Revista Brasileira de Linguística Aplicada, v. 17, n. 2 , p. 355-378.

WINDLE, J. A.; NOGUEIRA, M. A. (2015). The role of internationalisation in the schooling of Brazilian elites: distinctions between two class fractions. British Journal of Sociology of Education, v. 36, n. 1, p. 174-192.

Recebido: $7 / 12 / 2018$

Aceito: 21/02/2019

Publicado: 29/03/2019 